\title{
FEATURES OF ASSESSMENT OF LEVELS OF ACMEOLOGICAL COMPETENCE AMONG FUTURE SHIPPING NAVIGATORS IN THE PROCESS OF LEARNING ACTIVITIES
}

\author{
Mykola Kalashnik \\ Department of Pedagogy and Psychology of Primary Education \\ Kherson State University \\ 27 Universytetska str., Kherson, Ukraine, 73003 \\ Nikokalashik@gmail.com
}

\begin{abstract}
.
The article is devoted to the problem of assessing the effectiveness of the formation of acmeological competence of future navigators in the process of their professional training. And taking into account the specifics of their professional activities, the main objects of pedagogical diagnostics of the formation of the level of acmeological competence of future navigators are: acme-awareness, acme-praxis, acme-quality, acme-ability, acme-properties, value orientations and motivation, activity of interaction with the external environment, the effectiveness of subject-cognitive activity.

The key in pedagogical measurement is the definition of assessment criteria corresponding to the indicators of the named education. According to the main provisions of the theory of pedagogical measurement, the article highlights the criteria for the formation of the acmeological competence of future navigators with the corresponding indicators of their manifestation, the distribution of which is determined by: motivational, cognitive, praxeological and personal criteria, makes it possible to effectively evaluate the corresponding complexes of indicators of the state of formation of acmeological competence. In addition, in the course of the study, a three-level system of forming the acmeological competence of future navigators was propaned: low, medium and high. Where the highest level of formation of acmeological competence is characterized as - the level of actual "acme", which future navigators must achieve in their personal and professional development while studying in educational institutions.
\end{abstract}

Keywords: future ship navigators, acmeological competence, criteria and indicators of assessment, levels of formation, actual "acme".

DOI: $10.21303 / 2504-5571.2021 .001755$

\section{Introduction}

Technological renewal of the fleet and information saturation of the content of higher maritime education of specialists for water transport has been actively accelerating in recent years, and requires corresponding changes in the content of professional training [1]. This applies not only to the purely professional competencies of future specialists, but also to the personal sphere of cadets in the process of educational activities. Acmeological competence, as a component of the professional competence of future navigators, in this perspective occupies the most important place, since it substantively unites and integrates personal and professional characteristics [2-5]. Therefore, the substantiation of criteria and indicators for assessing the level of formation of acmeological competencies of future navigators is important when rethinking and updating the educational process.

Proceeding from this, the assessment of the formed acmeological competence includes pedagogical diagnostics (recognition and installation of signs that characterize the course of the pedagogical process [6, p. 261]. And pedagogical measurement (providing, using clearly defined rules, the numerical value of a certain indicator in accordance with its quantitative manifestations [7, p. 8]) set parameters.

The development of I. Bulakh [7], S. Courland [8], V. Monakhov, I. Pidlasyi [9] is devoted to the disclosure of the criteria and indicators of the course of various pedagogical processes. The named authors provide such interpretations of the concept of "criterion": an indicator, an objective manifestation of something [7]; the rule to be used when diagnosing [8]; a yardstick for determining, evaluating an object, phenomenon; a feature taken as the basis for the classification is a measure of assessment and judgment, as a necessary and sufficient condition for the manifestation or existence of any phenomenon or process [9]. 
The term "indicator" is defined as "a sign of something, a quantitative characteristic of the properties of a certain process, phenomenon or event, on the basis of which conclusions can be drawn about the course of this process" [9]. Based on this, distinguish between qualitative and quantitative, regulatory and analytical indicators. Qualitative indicators record the presence or absence of measurable properties, signs and sides, quantitative indicators - the measure of their development and severity. Normative indicators serve as guidelines in the study, analytical indicators reflect the relationship, dependence between several one-level or multi-level investigated properties or sides of the subject. An indicator is a quantitative or qualitative part of a criterion, a characteristic of an object, process or phenomenon; the concept of "level" reproduces the dialectical nature of the development process, allows one to cognize an object in all the variety of its properties, connections and relations [10].

So, the aim of the article is to substantiate the criteria and indicators for assessing the level of formation of acmeological competencies of future navigators.

\section{Materials and Methods}

Despite the fact that the criteria are used to determine those qualities of a phenomenon or process that reflect its essential characteristics, under the criterion of the level of formation of the acmeological competence of future navigators, let's mean a qualitative feature or a quantitative assessment of individual components of the object under study; the indicator defines the formation of each criterion as a qualitative or quantitative characteristic.

In many scientific and pedagogical studies, the requirements for indicators are justified, namely: indicators should be understandable, specific-meaningful, uniform for a given system, available for measurement; there should be a minimum number of them, since the assessment procedure should be as simple as possible. General requirements for the selection and justification of criteria and indicators boil down to the fact that the criteria should be transparent; provide for the possibility of quantifying indicators; reflect the main patterns of development of the studied phenomenon; for each criterion, the number of indicators must be more than three; using the criteria, connections should be established between all components of the system under study; qualitative indicators should act in unity with quantitative ones [11, p. 90]. The manifestation of the main indicators gives the basis for the conclusion about the level of formation of the criterion. So, the criterion determines the qualities and properties of the object under study, and the indicator - the degree of formation of each criterion. That is, the choice of a criterion leads to the correct choice of a certain system of indicators, the quality characteristics of which depend on how they objectively characterize a certain criterion.

Under the level, let's understand - the ratio of "higher" and "lower" levels of development of indicators, that is, the level is a certain "peak" achieved in the process of education formation. The acmeological competence of future navigators moves to a higher level if the manifestation of the development of its elements deepens or closer ties are created between them [11]. Based on the main provisions of the theory of the stepwise approach, let's distinguish three degrees of development of each criterion for the formation of acmeological competence.

Taking into account the specifics of professional activity, the main objects of pedagogical diagnostics of the formation of the level of acmeological competence of future navigators were chosen:

- acme-awareness (content and volume of acme-knowledge);

- acme-praxis (level of manifestation of acme-skills, range of experience)

- the formation of professionally important personal acme-qualities, acme-abilities and acme-properties;

- value orientations and motivation (direction of actions and behavior);

- activity of interaction with the external environment;

- effectiveness of subject-cognitive activity.

To measure the named objects, four criteria were chosen for the formation of the acmeological competence of future navigators with the corresponding indicators of their manifestation, the distribution of which is presented to the relevant criteria, namely:

- motivational, since motivation is a set of factors that determine the activity of a person [12], the process of motivation to activity and the achievement of certain goals [13], the process of mental regulation of a specific activity, or as a whole system of processes responsible for the 
activity. Despite this, in motivation let's understand "a dynamic psychophysiological process that controls human behavior, determines its direction, organization, activity and stability, as well as the ability of a person to satisfy its needs in action" [14].

Taking into account the above, the motivational criterion determines the presence of internal and external motives (needs) among applicants, prompting the formation of acmeological competence - an integral part of their future professional activity. According to this criterion, it is determined: understanding the meaning and role of the named competence in ensuring an appropriate level of life and personal safety, in the successful fulfillment of professional tasks, the formation of socially and professionally significant values, the internal need for personal and professional self-improvement, and further development of acmeological competence.

- a cognitive criterion characterizing the applicants' awareness of the methods and ways of performing professional tasks and is determined by the volume, completeness, depth and consistency of acme-knowledge necessary for successful professional activity [15]. The cognitive criterion is manifested in the volume and level of assimilation of knowledge, understanding of the essence and context of their application, the ability to critically analyze and generalize information, reproduce the system of acme concepts for solving specific professional problems.

- praxeological criterion characterizes the ability of applicants to use acme-knowledge when independently solving professional problems, manifests itself through the manifestation of acme-skills for self-identification, self-awareness, self-control and self-esteem and the sustainability of the use of acquired knowledge, the adequacy of actions and behavior in decision-making [7]. This criterion makes it possible to study the subject-cognitive and other types of activity of future navigators through the prism of its effectiveness. The indicators of the criterion are the formation of professionally necessary skills (technological, organizational and managerial, communicative, psychological and pedagogical); the level of proficiency in methods and methods of independent solution of professional problems; a range of professionally oriented experience (subject-cognitive activity); the ability to carry out self-identification, self-control, introspection and self-assessment of the results of professional activity.

- personality criterion is characterized by the presence of professionally important personal acme-qualities and acme-abilities, which determine the result of professional activity. It is aimed at identifying the ability of future navigators to realize their own abilities, capabilities and resources, reflect on the results of personal and professional development, focus on self-improvement [4]. When determining the content of the personality criterion, let's proceed from the fact that the inclinations of a person are innate, biologically determined opportunities for development; Ability is a biologically and socially determined potential of a person to perform a certain type of activity (mental, professional); qualities are relevant to the personality traits, thanks to which a person can achieve a certain development of abilities, success in activities, communication and establishing communication with others.

The following methods are used to diagnose these indicators: observation, questioning, interviews, testing, cadets' written work, their self-reports and reports of the teachers of maritime institutions. By the manifestation degree of indicators for each criterion, the corresponding level of formation of acmeological competence is determined.

\section{Results}

The study identified a three-level system for the formation of acmeological competence of future navigators: low, medium and high. Based on certain criteria and related indicators, the respective levels have been determined.

The low level of formation of acmeological competence characterizes the cadets of maritime institutions, which are characterized by an indifferent attitude to the subject-cognitive (future professional) activity. This level of character is based on general ideas about the role and significance of acmeological competence; low motivation for professional communication and a weak desire for interaction; the absence of an internally personal need for the formation of acmeological competence and a low level of motivation for personal and professional self-improvement; lack of direction for professional recognition, career development.

Cadets lack acme knowledge (in particular, about the rules and norms of communication, verbal and non-verbal interaction, tactics and strategies of personal and professional self-improve- 
ment, mechanisms and methods of self-control and self-assessment), they are not sufficiently familiar with the methods and ways of performing professional tasks. They do not know how to productively communicate and interact, do not show activity, do not use acme-knowledge in practice and in the classroom in professionally oriented and general academic disciplines, do not demonstrate the ability to make effective professional and managerial decisions and be responsible for them; have limited experience in performing professional tasks on their own. The level of development of psychomotor skills is low, a low level of stress resistance, the list and degree of development of professionally important abilities and qualities is insignificant, weak reflection of the results of personal and professional self-development. Cadets show episodic adequacy of actions in typical situations, they lack the ability to act in non-standard circumstances, they are not able to adequately respond to stimuli, they do not realize their capabilities, they can't determine the purpose and significance of their activities in using resources and their own potentials, but they have an overestimated self-esteem own competitiveness ability in the labor market.

The average level of formation of acmeological competence is inherent in cadets with a predominantly positive attitude towards future professional activities. And although they are characterized by an unconscious motivation for professional communication and an unstable desire for interaction, the existing situational need for the formation of acmeological competence, sufficient motivation for personal and professional self-improvement and a pronounced motivation for personal and professional self-development. Future navigators demonstrate an understanding of the role and importance of acmeological competence for the successful performance of professional tasks, in particular for the prevention or resolution of conflicts. At this level, there is a well-developed ability to substantiate the peculiarities of interaction and cooperation on board the ship, to analyze the consequences of erroneous decisions.

Future navigators already have a certain amount of acme knowledge, but they are unsystematic. At the same time, they have knowledge of the rules and ethical norms of communication, the characteristics of verbal and non-verbal interaction, methods and ways of performing professional tasks, knowledge of the mechanisms and methods of self-control and self-assessment, tactics and strategy of personal and professional self-development. Professionally important acme-knowledge is partially systematized, although there is an insufficiently deep understanding of the need for their application in the performance of professional tasks. Cadets strive to use various forms of work, while showing a fairly deep knowledge of the essence of collective interaction. They demonstrate sufficient acme-knowledge from general academic and professionally oriented disciplines, however, in non-standard situations, they sometimes experience difficulties in identifying acme-skills in professional activities. In standard situations, the speed of reaction to events or stimuli is quite high, balance, criticality and flexibility of thinking are observed.

The cognitive activity of future navigators is conscious and aimed at results, however, responsibility for the quality of work is sporadically. Cadets are aware of their own abilities and properties, they can determine the purpose and meaning of their activities, show a sufficient level of activity. There is already a certain list and an average degree of development of professionally important abilities and qualities, a certain ability to reflect on the results of personal and professional self-development and a partial ability to self-improvement through the definition of more complex professional tasks. The skills to exercise self-control and self-analysis of activity are not fully formed, however, self-assessment of one's own competitiveness in the labor market is still biased.

The high level of formation of acmeological competence characterizes the cadets of the HMEI, who are distinguished by a positively active attitude to mastering their chosen profession, and which is characterized by a purposeful striving for personal and professional self-improvement and career development, professional recognition. They formulate a complete understanding of the role and significance of acmeological competence as a means of achieving personal and professional "acme". Future navigators already have a conscious need to participate in the life support of other crew members and a conscious motivation for professional communication, a steady desire for mutual understanding and interaction.

Future navigators with such a level demonstrate systemic deep acme knowledge, are able to quickly navigate in various situations of professional interaction (in particular non-standard ones), react 
to the actions of others, make the right decisions and be responsible for them; strive to prevent the emergence of conflict situations and are able to solve them [16]. Activity, energy, formation of professionally significant value orientations and emotions, contributing to the achievement of certain goals of subject-cognitive activity, are characteristic of such cadets. Representatives of this group are characterized by a high level of development of professionally important personal qualities and abilities; they note the absence of emotional tension when performing professionally oriented tasks, an awareness of the importance and empathy for those around them. Such cadets are distinguished by expressive speech, argumentation and vividness of thoughts, the ability to convince in their justified rightness.

Stable accuracy in the performance of standard professional tasks [1], an insignificant number of shortcomings and the identification of a creative approach when solving non-standard situations is due to the mastery of individually significant acme knowledge, the ability to apply this knowledge, an adequate manifestation of professionally important qualities and abilities, mastering the content, methods and ways of performing professional activities. Cadets are characterized by a high level of self-organization and the ability to plan, control, regulate and analyze their activities; they are capable of taking responsibility for the quality and results of their work.

\section{Discussion}

The defined levels exist in a logical and hierarchical sequence, but they are not isolated from each other; each level includes the achievement of the previous one, but expands and complements the characteristics, as noted by O. Zabolotska [17]. At the same time, the allocation of a certain level determines the formation of a certain competence, without which it is impossible to move to the next level.

At the same time, with a low level of formation of acmeological competence, educational activity seems monotonous and uninteresting to cadets, their subject-cognitive activity, according to O. Frolova [6], is reproductive. Acme-knowledge is incomplete and superficial, acme-skill is not developed, acme-skills are not worked out. Future navigators are confident in expressing their own thoughts and views, can't argue and defend them, are not able to convince others of their rightness; do not show the initiative for personal and professional self-improvement at all. Although L. Gerganov believes that this circumstance does not hinder their development [15].

With an average level of formation of acmeological competence, educational activity is recognized through the development of professionally necessary knowledge and skills, subject-cognitive activity becomes creatively reproductive. Future navigators are confident in their own views and beliefs, they know how to position them, but they do not know how to argue; the initiative for personal and professional self-improvement is detected with a certain frequency. At the same time, G. Varvaretska argues that for the professional readiness of future navigators, the average level of competence formation is not enough, especially when solving critical situations [10].

When applicants reach a high level, they have formed technological acme-competencies, organizational and managerial, communicative, psychological and pedagogical acme-skills necessary for effective professional activity, and adequately assess their own competitiveness. Along with this, the presence of positive emotions that arise in the process of professional interaction, a high degree of tolerance for the uncomfortable states of others, and the ability to adapt to the characters and habits of other crew members are characteristic. In such applicants there is a desire to achieve high professional results. Although, according to L. Gerganov, in some cadets, with an intense load, "burnout" is observed [12]. Despite this, it is possible to note that with a high level of formation of acmeological competence of future navigators, they approach educational activities creatively [1], show initiative in subject-cognitive activity.

\section{Conclusions}

The analysis of scientific sources made it possible to clarify the content of the concepts "criterion" and "indicator" and to substantiate the essence of the criteria and indicators of the formation of the acmeological competence of future navigators [18]. Four criteria (motivational, cognitive, praxeological, personal), indicators and the corresponding levels (low, medium, high) of formation of acmeological competence, characterizing the result - the level of actual "acme", which future navigators must achieve in their personal and professional development in time of study in educational institutions. 


\section{Acknowledgments}

We express our gratitude to the teachers and cadets of the Kherson State Maritime Academy, who took an active part in the study of the levels of acmeological competence.

\section{References}

[1] Oksavik, A., Hildre, H. P., Pan, Y. (Eds.) (2020). Future skill and competence needs. Available at: https://www.skillsea.eu/ images/Public_deliverables/D1.1.3\%20Future\%20Skills\%20and\%20competence\%20needs_final\%20version(1).pdf

[2] A Framework for Defining and Assessing Occupational and Training Standards in Developing Countries Information Series No. 386 (2001). Available at: https://unevoc.unesco.org/e-forum/A_Framework_for_Defining_Training_Standards.pdf

[3] Vocational Training (Seafarers) Recommendation 1970 (No. 137) Available at: https://www.ilo.org/dyn/normlex/ en/f?p=NORMLEXPUB:55:0::NO::P55_TYPE,P55_LANG,P55_DOCUMENT,P55_NODE:REC,en,R137,/Document

[4] The mapping of career paths in the maritime industries. A project by Southampton Solent University for the European Community Shipowners' Associations (ECSA) and the European Transport Workers Federation (ETF) with the support of the European Commission. Available at: https:/www.ecsa.eu/images/files/downloads_publications/054.pdf

[5] Mulder, M. (2001). Competence development - some background thoughts. The Journal of Agricultural Education and Extension, 7 (4), 147-158. doi: http://doi.org/10.1080/13892240108438822

[6] Frolova, O. O. (2013). Osoblyvosti profesiinoi pidhotovky sudnovodiiv u vyshchykh navchalnykh zakladakh. Psykholoho-pedahohichni zasady diialnosti fakhivtsia: istoriia, teoriia, praktyka. Kherson: KVNZ «Khersonska akademiia neperervnoi osvity», 260-262.

[7] Bulakh, I. (2010). Psykholohichnyi analiz vyvchennia vnutrishnoosobystisnykh konfliktiv u zarubizhnykh ta vitchyznianykh dzherelakh. Mizhnarodnyi naukovyi forum: sotsiolohiia, psykholohiia, pedahohika, menedzhment, 2, 108-118. Available at: http://nbuv.gov.ua/UJRN/Mnf_2010_2_12

[8] Kurliand, Z. N., Khmeliuk, R. I., Semenova, A. V. et. al.; Kurliand, Z. N. (Ed.) (2007). Pedahohika vyshchoi shkoly. Kyiv: «Znannia», 495.

[9] Pidlasyi, I. P. (2010). Produktyvnyi pedahoh. Nastilna knyha vchytelia. Kharkiv: «Osnova», 360.

[10] Varvaretska, H. A. (2013). Pedahohichni umovy formuvannia profesiinoi spriamovanosti maibutnikh fakhivtsiv morskoho ta richkovoho transportu u protsesi matematychnoi pidhotovky. Nauka i osvita, 6, 78-82.

[11] Maiboroda, A. A. (2014). Tekhnologiia formirovaniia akmeologicheskoi kompetentnosti kursantov. Vestnik komandno-inzhenernogo instituta MCHS respubliki. Belarus, 2 (19), 89-95.

[12] Lyska, S. I. (2012). Kompetentnisnyi pidkhid u doslidzhenni profesiinoi uspishnosti osobystosti. Vyshchyi navchalnii zaklad «Universytet ekonomiky ta prava «KROK». Vol. 13. Kyiv, 268.

[13] Dereka, T. H. (2015). Akmeolohichni zasady neperervnoi profesiinoi pidhotovky fakhivtsiv fizychnoho vykhovannia: kontseptsiia doslidzhennia. Pedahohichni nauky: teoriia, istoriia, innovatsiini tekhnolohii, 7 (51), 31-39.

[14] Zablotska, O. S. (2008). Kompetentnist, kvalifikatsiia, kompetentsiia yak kliuchovi katehorii kompetentnisnoi paradyhmy vyshchoi osvity. Visnyk Zhytomyrskoho derzhavnoho universytetu imeni Ivana Franka, 39, 52-56.

[15] Herhanov, L. D. (2016). Rozvytok profesiinoi kompetentnosti kvalifikovanykh fakhivtsiv morskoho profiliu v navchalnykh tsentrakh sudnoplavnykh kompanii: tendentsii ta perspektyvy. Naukovyi visnyk Mykolaivskoho natsionalnoho universytetu imeni V. O. Sukhomlynskoho, 1, 76-82.

[16] Quantifying skill needs in Europe Occupational skills profiles: methodology and application (2013). Luxembourg: Publications Office of the European Union. Available at: https:/www.cedefop.europa.eu/files/5530_en.pdf

[17] McKinnon, A., Flöthmann, C., Hoberg, K., Busch, C. (2017). Logistics Competencies, Skills, and Training: A Global Overview. doi: http://doi.org/10.1596/978-1-4648-1140-1

[18] Progoulaki, M., Roe, M. (2011). Dealing with multicultural human resources in a socially responsible manner: a focus on the maritime industry. WMU Journal of Maritime Affairs, 10 (1), 7-23. doi: http://doi.org/10.1007/s13437-011-0003-0

Received date 03.02.2021

(C) The Author(s) 2021

Accepted date 10.03.2021

Published date 31.03.2021

This is an open access article under the CC BY license (http://creativecommons.org/licenses/by/4.0).

How to cite. Kalashnik, M. (2021). Features of assessment of levels of acmeological competence among future shipping navigators in the process of learning activities. EUREKA: Health Sciences, 2, 38-43. doi: http://doi.org/10.21303/2504-5571.2021.001755 